This is the peer reviewed version of the following article: Rodner, V. L. (2015), A Tale of Two Cities: Can Socioeconomic Factors Thwart Creativity in London and Berlin?. Symbolic Interaction, 38: 631-633, which has been published in final form at https://doi.org/10.1002/symb.191. This article may be used for non-commercial purposes in accordance With Wiley Terms and Conditions for self-archiving. 


\title{
A tale of two cities: can socio-economic factors thwart creativity in London and Berlin?
}

Victoria L. Rodner

King's College London

\author{
Artistic Lives - A study of Creativity in Two European Cities \\ By Kirsten Forkert \\ Farnham, England: Ashgate Publishing Limited.
}

In this dual-city examination of the lives of visual artists, Forkert presents us not only with the key findings of her doctoral research, but also with a personallymotivated reflection on the autonomy of artistic practice. A freelance artist, critic and arts manager herself, Forkert is truly an insider of this complex universe of the arts, making her all the more sympathetic and attuned to the obstacles that visual artists face in establishing their careers within a neoliberal context. Nonetheless, her qualitative approach to the study is sound and well structured, adopting an ethnographic style to data collection and analysis. For Artistic Lives, Forkert interviewed 41 artists, intermediaries and academics in London and Berlin as well as conducting extensive fieldwork in both locations. Although each city presented very different settings (and hence responses), this comparison highlights some of the key issues affecting visual artists today, namely the socio-economic conditions and class privileges of visual artists living in these two European capitals. Forkert has peppered the chapters with ethnographic accounts of artists and locations to help paint a clearer picture of the cultural scene, making her findings all the more vivid and tangible for the reader.

As contemporary art continues to play a substantial role in shaping a global lifestyle industry, Forkert explores how social conditions can essentially affect cultural production. Beyond an exploration of aesthetics, gentrification, or cultural policies, Forkert brings us face-to-face with the realities that visual artists face in making a career for themselves, considering issues such as housing prices, juggling parallel jobs or casual work in order to pay for their art, access to studio spaces and possibilities to disseminate their work, and the fostering of artistic communities.

After a succinct introduction, which covers the motivations and background to the research, the context and research method, key findings and general layout, Chapter 1 'Capitalism and the Figure of the Artist' and Chapter 2 'The Creative Subject and the State' place us firmly within the theoretical framework of the study. In Chapter 1, she considers the figure of the artist as allegedly emancipated from wider socio-economic conditions (a modern day 'bohemian'), a claim she demystifies with her findings. She also considers how artists tend to juggle multiple jobs, which can in turn detract from their perceived seriousness as a creative individual. In Chapter 2 she explores the purposeful investment in a cultural infrastructure, the use of art as a 'soft' power, and the cultural policies that have helped shape the creative economy.

Chapters 3 and 4 ('The Loss of Space and Time for Creative Activities in London' and 'Shortened Careers and Pressures for Instant Success') delve straight into Forkert's findings on the London art scene. Over these two chapters she reveals how one of the world's irrefutable art hubs is in fact relatively inhospitable for visual artists, who struggle with the high cost of living, expensive housing options, access to 
art funds (that tend to be bureaucratic, time-consuming and inflexible), and limited returns from the art market. Due to their middle class background, visual artists tend not to rely on benefits to make ends meet, opting instead for part or even full-time employment in other fields to finance their art. This dual-career path directly affects not only the time and energy dedicated to producing art, thereby shortening their careers, but also destabilises their own sense of identity as a 'serious artist'. Forkert concludes that stable accommodation can enable art to happen and encourage art communities to flourish in a more organic manner. However, the current situation shows how many visual artists opt to relocate from central London, thereby breaking the creativity chain altogether.

Berlin presents a rather different art scene altogether. In Chapters 5 and 6 ('Berlin: An Economy Based on the Marketing of Creativity' and 'Does Berlin Present an Alternative Model for Cultural Production'), Forkert notes how the German capital proves to be a much more affordable option for visual artists. Historically the city has witnessed a substantial de-industrialisation and flight of the middle-class to the peripheries following reunification, making living and studio spaces more available for artists. Berlin has positioned itself as a site for an art production, not necessarily art sales, thereby encouraging many forms of art practice, symbolic dissemination and naturally, the emergence artistic communities. Unlike their London counterparts, artists in Berlin tend not to establish dual-careers to make a living, but rather support themselves with casual work or 'mini jobs', surviving on a low-wage economy. This 'bohemian' lifestyle helps set Berlin as a trendy city and continues to be an attractive centre for arts production.

Forkert concludes that material conditions $d o$ in fact matter in the production of art. Via her dual-city examination, she has presented us with an intimate and moving account of the lives of artists, where she demystifies the figure of the artist as a detached 'bohemian', revealing the vulnerability and challenges of this career choice. Forkert's findings are both relevant and easily transferable to other contexts and Artistic Lives will be well received by artists, art professionals, art scholars and sociologists, cultural managers, policy writers and urban theorists alike. In her examination of these two cultural hubs, she presents us with a thoroughly enjoyable and insightful account of the lives of visual artists and her findings on cultural networks and the dynamics of the art world will resonate with fellow readers of Symbolic Interaction.

\section{ABOUT THE CONTRIBUTOR(S)}

Victoria L. Rodner is an independent researcher and doctoral graduate from King's College London (Department of Management). Her research interests include the legitimation and symbolic validation of the visual arts market, macroenvironmental pressures on cultural dissemination, institutional theory and organizational analysis, branding/marketing discourses, and emerging markets. 